\title{
Cognitive function assessment on tuberculosis among senior school students in south Chennai, India
}

\author{
Parthasarathy Jaganathan Parameaswari ${ }^{1,}$, , Panjetty Manickam Udayshankar ${ }^{1}$, \\ Chitralekha Saikumar ${ }^{2}$, Dhanapal Bindu ${ }^{2}$, Annasekaran Abiselvi ${ }^{1}$, Pandurangan Mohankumar ${ }^{1}$, \\ Chinnaian Sivagurunathan ${ }^{1}$, Murugan Dhanapal Vidhyashree ${ }^{1}$, Syed Iqbal Sultan ${ }^{1}$ \\ ${ }^{1}$ Dept.of Community Medicine, Sree Balaji Medical College and Hospital, Bharath University, Chennai, India \\ ${ }^{2}$ Dept.of Microbiology, Sree Balaji Medical College and Hospital, Bharath University, Chennai, India
}

\section{Email address:}

dr.parameaswari@rocketmail.com (P. J. Parameaswari)

\section{To cite this article:}

Parthasarathy Jaganathan Parameaswari, Panjetty Manickam Udayshankar, Chitralekha Saikumar, Dhanapal Bindu, Annasekaran Abiselvi, Pandurangan Mohankumar, Chinnaian Sivagurunathan, Murugan Dhanapal Vidhyashree, Syed Iqbal Sultan. Cognitive Function Assessment on Tuberculosis among Senior School Students in South Chennai, India. European Journal of Preventive Medicine. Vol. 1, No. 2, 2013, pp. 46-49. doi: 10.11648/j.ejpm.20130102.12

\begin{abstract}
SETTING: A Sub-Urban private higher secondary School. OBJECTIVES: To determine students' knowledge on tuberculosis. DESIGN: Students from the eleventh standard were interviewed using structured questionnaire about the disease before and after Health Education. RESULTS: A total of 78 students with a mean \pm SE age of $15.1 \pm 0.08$ years (range14-17 years) Participated \& Forty Three (55.0) who acquired knowledge about TB from Health professionals was found to be the main source of information. Students had 'adequate knowledge' about tuberculosis before Health Education as well McNemar's test showed a statistically significant major shift in proportion of students from 57.7 to $89.7(\mathrm{P}=0.000)$ for correct response from 'adequate' knowledge to 'exemplary' knowledge. Sixty three (80.8) from nuclear Family contributed to a significant improvement in post test Knowledge of TB. Students of those Parent with tertiary education had better knowledge than others. CONCLUSION: Audio Visual mode of Health Education on TB had improved the Cognitive Skill among the students. Adequate education on tuberculosis will help the younger generations to prevent $\mathrm{TB}$ in future.
\end{abstract}

Keywords: Knowledge, Tuberculosis, Health Education, Public Health, Preventive Measures

\section{Introduction}

Tuberculosis (TB) - A Pandemic, by definition, plays out on a massive scale - is a major Global Health problem. Each year there are around nine million new cases of TB and close to two Million deaths [1]. In 2012, 182 Member states and a total of 204 countries and territories that collectively have more than $99 \%$ of the World's TB cases reported data. Geographically the Burden of TB is highest in Asia and Africa. India and China account for almost $40 \%$ of the World's TB cases. Research to develop a point-of-care diagnostic test for TB and MDR-TB continues and other diagnostic tests are in the pipeline [2].

Awareness regarding Tuberculosis is very important for the School Children since it mostly affects young adults in their most productive years of life. India accounts for one fifth of global burden of Tuberculosis with two third cases in SEAR. It is more prevalent among adults i.e. more than $70 \%$ of TB cases are in the most productive age-group (15-54) years, causing a Socio-Economic burden with an annual loss of 170 million workdays wherein $2 / 3^{\text {rd }}$ of them are males [3].

\subsection{Rationale of the Study}

The Indian Government declared TB as NOTIFIABLE disease on May 17, 2012 [4]. Hence as researchers with Public Health responsibility from a Tertiary Care Medical College \& Hospital, felt the need in delivering the preventive and curative measures on TB to the younger generation. The main aim was to assess the cognitive domain of learning about the TB disease before and after Health Education. This study was approved by the Research and Ethical Committee of our Institution.

\section{Materials and Methods}

Design: Educational Intervention Study

Place: Government recognized Private Higher

Secondary School in South Chennai, India. 
Participants: Students aged(14-17)years in $11^{\text {th }}$ standard Period: Nov 2012 to Mar 2013

Sampling Technique: Balanced Panel Sampling [5] at two time points, Two Higher Secondary Schools (one-Govt. \& one - Pvt.) from the Sub-Urban area were chosen. All students from the randomly selected Private School were included in the study with the written informed consent from their parents too.

Sample Size: Assuming that $50 \%$ of the students will be aware about TB, The minimum required sample size was estimated to be 29 with 5\% Type I error, limit of accuracy of $20 \%$ and an attrition of $20 \%$. [6]

Methodology: Students cognitive skill was assessed before and after Health Education on TB by experienced Professionals over an interval of 4 months.

Material: A structured Questionnaire [7] with Demographic information and 16 items assessing knowledge on TB ( closed type response) was used.

Intervention : Health Education on TB disease [ Audio Visual (Power Point presentation)] by Professor in Microbiology (Fig 1.) and Preventive aspects on TB by Professor in Community Medicine (Fig 2.) for nearly 45mts.

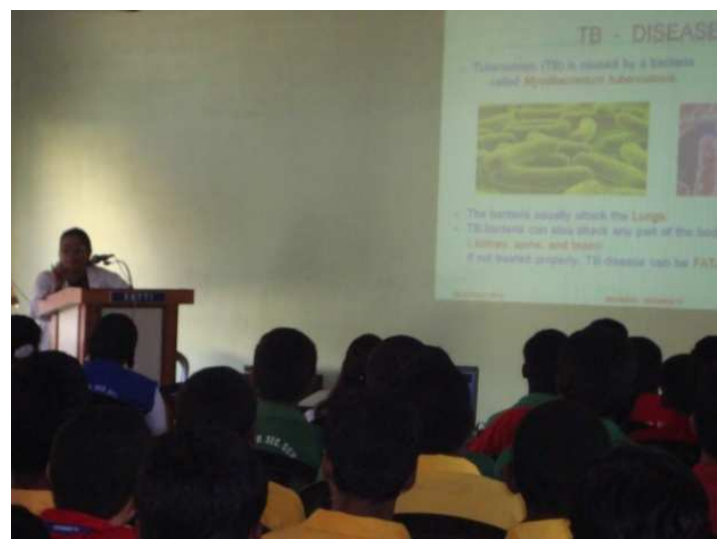

Fig 1. Professor of Microbiology

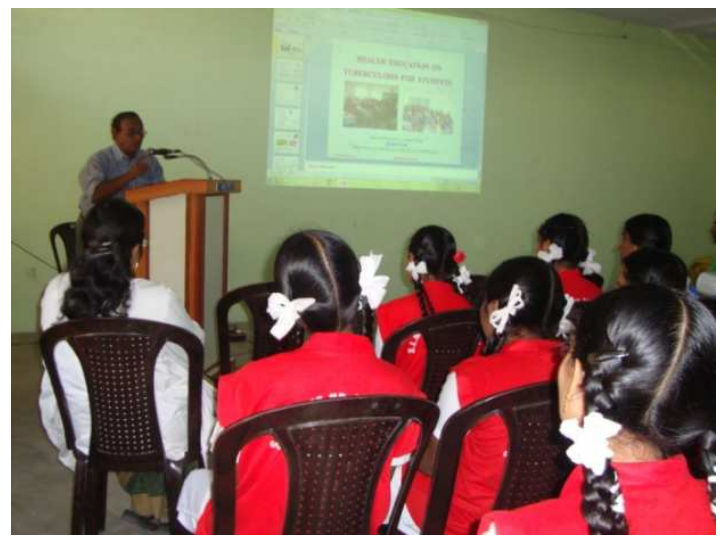

Fig 2. Professor of Community Medicine

Statistical Analysis: The baseline \& TB information were analyzed using (SPSS 15.0). The results are presented as frequency, percentage along with inferential tests Chi Square and McNemars Chi-Square,[8] at 5\% level of significance. The values within parentheses represent percentage.

Results: The present study had forty two (53.8) males and thirty six(46.2)females with a majority seventy two (92.3) hindus and all participants were residing in their home and commuted by the Metro Transport from a distance ranging between $(5-10) \mathrm{km}$ to the school. From Table 1 we observe that Sixty three (80.8) of them hailed from the nuclear family and twenty nine (37.2) parents had a highest educational qualification to be Tertiary and Sixty seven (85.9) were skilled employers with a maximum forty three (55.1) had a PCI of 2000 and above.

Table 1: Demographic Information of Students

\begin{tabular}{|c|c|c|c|}
\hline \multicolumn{2}{|r|}{ Variables } & $\mathbf{N}$ & $\%$ \\
\hline \multirow[t]{2}{*}{ Sex - } & Male & 42 & 53.8 \\
\hline & Female & 36 & 46.2 \\
\hline \multirow[t]{3}{*}{ Religion- } & Hindu & 72 & 92.3 \\
\hline & Muslim & 3 & 3.8 \\
\hline & Christian & 3 & 3.8 \\
\hline \multirow[t]{2}{*}{ Residence- } & Home & 78 & 100.0 \\
\hline & Hostel & 0 & 0.0 \\
\hline \multirow[t]{5}{*}{ Parent Educ } & ation - Illiterate & 3 & 3.8 \\
\hline & Primary & 1 & 1.3 \\
\hline & Secondary & 19 & 24.4 \\
\hline & Higher Secondary & 24 & 30.8 \\
\hline & Tertiary & 29 & 37.2 \\
\hline \multicolumn{2}{|c|}{ Parent Occupation - Professional } & 4 & 5.1 \\
\hline & Managerial & 5 & 6.4 \\
\hline & Clerk \& Skilled & 67 & 85.9 \\
\hline & Semiskilled & 1 & 1.3 \\
\hline & Unskilled & 1 & 1.3 \\
\hline \multirow[t]{2}{*}{ Family Type } & Joint & 15 & 19.2 \\
\hline & Nuclear & 63 & 80.8 \\
\hline \multirow[t]{2}{*}{ Diet - } & Vegetarian & 13 & 16.7 \\
\hline & Mixed & 65 & 83.3 \\
\hline \multicolumn{4}{|c|}{ PCI/month (BG Prasad 2011) } \\
\hline & $\geq 5000$ & 20 & 25.6 \\
\hline 2001 & -5000 & 23 & 29.5 \\
\hline 1251 & -2000 & 22 & 28.2 \\
\hline 1000 & -1250 & 7 & 9.0 \\
\hline & $<1000$ & 6 & 7.7 \\
\hline \multirow[t]{2}{*}{ Smoker - } & Yes & 3 & 3.8 \\
\hline & No & 75 & 96.2 \\
\hline \multirow[t]{2}{*}{ Alcoholic - } & Yes & 1 & 1.3 \\
\hline & No & 77 & 98.7 \\
\hline \multicolumn{2}{|c|}{ Source of Information - Mass Media } & 23 & 29.5 \\
\hline \multicolumn{2}{|c|}{ One to One Communication } & 43 & 55.1 \\
\hline & Both & 12 & 15.4 \\
\hline \multirow[t]{4}{*}{ Brothers - } & 0 & 45 & 57.7 \\
\hline & 1 & 30 & 38.5 \\
\hline & 2 & 2 & 2.6 \\
\hline & 3 & 1 & 1.3 \\
\hline \multirow[t]{3}{*}{ Sisters- } & 0 & 39 & 50.0 \\
\hline & 1 & 34 & 43.6 \\
\hline & 2 & 5 & 6.4 \\
\hline
\end{tabular}


Sixty five (83.3) students were on mixed diet, three(3.8) smokers and one(1.3) alcoholic, whereas ten (12.8) of their family members were smokers. The sources of information on TB revealed that twenty three (29.5) as Mass Media, forty three (55.1) from One to One (Health Professionals) communication and twelve (15.4) from both.

Before Health education twenty six (33.3) didn't know about extra-pulmonary TB, fifty nine (47.4) thought young adults are not affected. Thirty five (44.9) weren't aware about its free treatment as well as DOTS programme. Difference in the proportion of correct response before and after Health education was statistically significant only for few items and is provided in Table 2.

Table 2: Proportion of Students with Correct Response

\begin{tabular}{|c|c|c|}
\hline Questions & $\begin{array}{c}{[\mathrm{N}(\%)]} \\
\text { Before HE, After HE } \\
\end{array}$ & $\begin{array}{l}\chi^{2}-\text { value } \\
\text { (P-value) }\end{array}$ \\
\hline TB is caused by Bacteria & $64(82.1), 76(97.4)$ & $9.38(0.002)^{*}$ \\
\hline $\begin{array}{l}\text { Lung is the mostly affected } \\
\text { Organ }\end{array}$ & $64(82.1), 75(96.2)$ & $5.02(0.025)^{*}$ \\
\hline $\begin{array}{l}\text { TB also affects Kidney, } \\
\text { Bone, Spine \& Brain }\end{array}$ & $26(33.3), 65(83.3)$ & $2.26(0.133)$ \\
\hline $\begin{array}{l}\text { TB mostly affects Young } \\
\text { Adult }\end{array}$ & $41(52.6), 69(88.5)$ & $9.26(0.004)^{*}$ \\
\hline TB is Curable \& Preventable & $64(82.1), 74(94.9)$ & $9.31(0.002)^{*}$ \\
\hline $\begin{array}{l}\text { TB spreads from Person } \\
\text { to Person through Air }\end{array}$ & $76(97.4), 76(97.4)$ & $0.05(0.816)$ \\
\hline $\begin{array}{l}\text { Smoking is one of High risk } \\
\text { factor for } \mathrm{TB}\end{array}$ & $68(87.2), 76(97.4)$ & $2.53(0.111)$ \\
\hline $\begin{array}{l}\text { Cough \& Weight Loss are } \\
\text { common symptoms of TB }\end{array}$ & $74(94.9), 78(100.0)$ & No Difference \\
\hline $\begin{array}{l}\text { People ill with TB can infect } \\
\text { upto } 10-15 \text { people through }\end{array}$ & & \\
\hline $\begin{array}{l}\text { close contact over a period } \\
\text { of one year }\end{array}$ & $57(73.1), 72(92.3)$ & $1.75(0.185)$ \\
\hline TB treatment is free of cost & $35(44.9), 72(92.3)$ & $0.35(0.554)$ \\
\hline $\begin{array}{l}\text { Sputum AFB test is the } \\
\text { diagnostic test of choice }\end{array}$ & $42(53.8), 62(79.5)$ & $2.16(0.141)$ \\
\hline $\begin{array}{l}\text { DOTS refer to a method } \\
\text { of treatment of TB }\end{array}$ & $39(50.0), 70(89.7)$ & $0.00(1.000)$ \\
\hline $\begin{array}{l}\text { TB treatment is for } \\
6-9 \text { months }\end{array}$ & $50(64.1), 76(97.4)$ & $0.17(0.674)$ \\
\hline BCG vaccine prevents TB & $63(80.8), 72(92.3)$ & $9.41(0.002)^{*}$ \\
\hline $\begin{array}{l}\text { March } 24 \text { is WORLD } \\
\text { TUBERCULOSIS DAY }\end{array}$ & $59(75.6), 73(93.6)$ & $0.05(0.814)$ \\
\hline $\begin{array}{l}\text { Good Ventilation, Air } \\
\text { Filtration \& Isolation method } \\
\text { are preventive measures from } \\
\text { Active TB patients }\end{array}$ & $70(89.7), 70(89.7)$ & $7.18(0.107)$ \\
\hline
\end{tabular}

HE - Health Education; *Statistically Significant
So we decided to look into the weightage of the correct response. Hence all 16 items measuring knowledge on TB were given a Score of ' 1 ' for correct response and a ' 0 ' for incorrect answer. The proportion of students with correct response at two time points was assessed for each item by Chi- Square test. Since we didn't find much statistical significance for each item, we then converted the obtained scores to percentage and grouped their knowledge as $(0 \%$ to $50 \%)$

'INADEQUATE', (50\% to 75\%) 'ADEQUATE' and (75\% and above) 'EXEMPLARY'. Later we observed a statisti cally significant difference in each group, i.e. after Health Education, we could observe a major shift of scores for correct response [Fig 3.] from ADEQUATE to EXEMPLARY knowledge, i.e. $57.7 \%$ to $89.7 \%$ and was Statistically Significant with $\chi^{2}=12.5 \quad(P=0.014)$ [ McNemar - Bowker Test $=45.09(P=0.000)]$

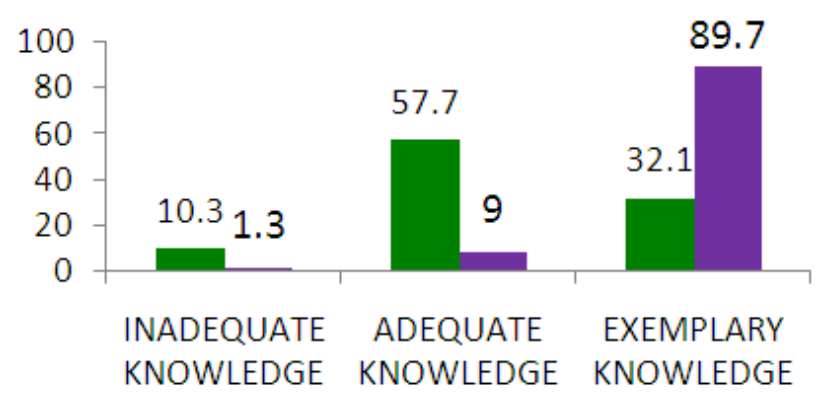

Fig 3. McNemar's Result on Health Education for TB

\section{Discussion}

Mycobacterium tuberculosis has been infecting the human race since the dawn of history. The prime objective of this community based study was to assess the effect of health education in improving knowledge about the disease among 78 adolescents by Balanced Panel

Sampling technique. We had Audio visual mode of health education session as intervention for measuring knowledge on TB amongst higher secondary school which was also implemented in Vijayaprasad study [9]. The questionnaire evaluated knowledge of TB transmission, prevention, and treatment. Almost all knew that TB is contagious and more than two thirds knew that $\mathrm{TB}$ is treatable and that $\mathrm{TB}$ preventive therapy existed. Our study did not have enough evidence whether their elder brothers and sisters contributed to their knowledge in TB.

After Health education in the present study overall correct response score was 98\%, among which $99 \%$ correct response to queries related to etiology, $98 \%$ for possible routes of transmission, $99 \%$ for symptoms, and $99 \%$ for treatment.

Knowledge deficits were observed in the etiology, transmission, and treatment of tuberculosis were identified as mentioned in the literature below. J.A. Corless [10] in his 
survey suggests that Knowledge about $\mathrm{TB}$ is limited in Computer Literate individuals throughout the World. Rahul $\&$ Sunil [11] felt, more studies are needed to assess the knowledge of postgraduate students on TB and its management practices in reference to RNTCP. Liam, CK et al [12] found that the Malaysian patients had limited understanding and knowledge about TB. Also they had misconceptions and limited knowledge about the disease and its treatment.

Singla [13] and his research team found that only $40.2 \%$ of tuberculosis nurses and $10.7 \%$ of general hospital nurses had a satisfactory level of awareness. There is a general lack of knowledge regarding various aspects of TB among Nurses. Lai, K.K.[14], said Only $87 \%$ of Health care workers with patient-contact felt that respiratory precautions should be instituted for TB patients. M.W. Uplekar,[15] study revealed gaps and weakness in the private doctors' reported practice of managing lung tuber culosis, the most important and persistent problem of public health concern in India.

\section{Conclusion}

The present study proves the importance of Health Education to the adolescents in school about TB, which is the need of the hour for our nation's younger generation. The priority was given more on the preventive aspect. Even though Audio Visual aid was effective in this study, the other modes of intervention like Role play, Group Discussion, Posters, Printed Handouts, Film Show, etc should also be experimented for the School Children. Active interventions are required to improve awareness for a better implementation of the revised national tuberculosis control programme in India.

\section{Acknowledgement}

We appreciate \& acknowledge the cooperation of the School Principal in granting permission to conduct the study as well the active participation of the students.

\section{References}

[1] http://www.stoptb.org/, THE GLOBAL PLAN TO STOP TB 2011-2015 by WHO
[2] http://www.who.int/tb/publications/global_report/gtbr12 main.pdf

[3] http://www.who.int/topics/tuberculosis/en/, WHO FACT SHEET MARCH 2012

[4] http://ehealth.eletsonline.com/2012/05/tb-declarednotifiable-disease-in-india/

[5] Hsiao, Cheng, 2003. Analysis of Panel Data, Cambridge University Press.

[6] Frees, E., 2004. Longitudinal and Panel Data, Cambridge University Press.

[7] Rao, P. S. S. Sundar, Richard, J., Introduction to Biostatistics and Research methods, $5^{\text {th }}$ ed, Jan 2012

[8] www.spss.com/

[9] Vijayaprasad Gopichandran et al. Impact of a simple educational intervention on the knowledge and awareness of tuberculosis among high school children in Vellore, India. Indian Journal of Community Medicine 2010; 35(1):174-75.

[10] J.A. Corless ${ }^{\text {a }}$,P.A. Stockton ${ }^{\text {b }}$,S.B. Myers ${ }^{\text {c }}$, P.D.O. davies ${ }^{\text {b, fl }}$, A world-wide internet survey of public knowledge about tuberculosis, Respir atory Medicine,Volume 96, Issue 1, January 2002, Pages 59-60.

[11] Rahul .R.Bogam, Sunil.M.Sagare. Knowledge of Tuberculosis and its management practices amongst Postgraduate medical students in Pune city, National Journal of Community Medcine, 2011,Vol.1,Issue.1,52-59

[12] Liam, C.K. ${ }^{\text {ab }}$, Lim, K.H. ${ }^{\mathrm{a}}$, Wong, C.M.M. ${ }^{\mathrm{a}}$, Tang, B.G. ${ }^{\mathrm{a}}$, Attitudes and knowledge of newly diagnosed tuberculosis patients regarding the disease, and factors affecting treatment compli -ance, International Journal of Tuberculosis and Lung Disease, Volume 3, Issue 4, April 1999, Pages 300-309

[13] Singla, N. ${ }^{\text {ab }}$, Sharma, P.P. ${ }^{\text {a }}$, Jain, R.C. ${ }^{\text {a }}$, Aware ness about tuberculosis among nurses working in a tuberculosis hospital and in a general hospital in Delhi, India, International Journal of Tuberculosis and Lung Disease, Volume 2, Issue 12, December 1998, Pages 1005-101

[14] Lai, K.K., Fontecchio, S.A., Kelley, A.L., Melvin, Z.S. , Knowledge of the transmission of tubercu losis and infection control measures for tubercu losis among healthcare workers,Infection Control and Hospital Epidemiology, Volume 17, Issue 3, March 1996, Pages 168-170

[15] M.W. Uplekar, S. Rangan, P rivate doctors and tuberculosis control in India, Tubercle and Lung Disease ,Volume 74, Iss.5, October 1993, Pages 332-337 